\title{
Pemilih Muda, Sosial Media dan Partisipasi Pemilih Pada Pemilihan Kepala Daerah Tulungagung 2018
}

\author{
Luthfi Ulfa Ni'amah \\ Jurusan Komunikasi dan Penyiaran Islam, Fakultas Ushuluddin, Adab \& Dakwah \\ Institut Agama Islam Negeri Tulungagung,66221, Indonesia \\ luthfiulfaniamah86@gmail.com
}

INFOARTIKEL

Riwayat Artikel:

DiterimaJuli 2018

Direvisi Agustus 2018

Disetujui September 2018

Kata Kunci: Pemilih muda, media sosial, partisipasi memilih

Keyword : Young voters, social media, political participation

\section{ABSTRAKSI}

Abstrak: Jumlah pemilih muda di Kabupaten Tulungagung mencapai 5\% dari Daftar Pemilih Tetap. Para pemilih muda ini memiliki pola interaksi dan komunikasi yang berbeda dengan generasi sebelumnya. Pemilih muda dipengaruhi oleh paparan media sosial yang tinggi dalam menentukan pilihan dan partisipasi politiknya. Penelitian ini ingin melihat informasi di media sosial yang disukai pemilih muda dalam membentuk pola partisipasi memilih mereka. Penelitian ini juga akan melihat intensitas memilih pemilih muda di Kabupaten Tulungagung. Metode penelitian deskriptif kualitatif diperkuat data kuantitatif dinilai mampu membendah permasalahan. Pemilih muda di Kabupaten Tulungagung lebih menyukai konten informasi politik di media sosial yang lebih umum. Mereka lebih menyukai konten politik di tingkat nasional dan provinsi dibanding lokal. Kesadaran memilih para pemilih muda di Kabupaten Tulungagung juga sudah muncul. Mereka memilih bukan dikarenakan tren namun kesadaran atas pilihan dalam pemilihan kepala daerah akan ikut menentukan nasibnya.

Abstract: Existing Voter List data from General Election Commission shows at least 5\% form Tulungagung voters are young. Young voters have different political interaction and communication pattern than the previous generation. Their voting and political participation behaviour is depends on social media exposure. This research wants to elaborate which kind of political content is likely most by young voters. This research also wants to elaborate Tulungagung's young voters voting intensity. Descriptive qualitative with additional quantitative data is choosen as research methods. Tulungagung's young voters prefer with general political information contents. They are preferred political information for both national and province level than local ones. They also vote based on their consciousness about the future of this nation than trend.

\section{Pendahuluan}

Bank Dunia mencatat jumlah penduduk Indonesia berada di angka 261,1 juta jiwa. Sebanyak 66\% jumlah penduduk Indonesia pada rentang tahun 2012 hingga 2030 berada di usia produktif antara 15 sampai 64 tahun. Pada konteks politik menunjukkan karakteristik pemilih di Indonesia sebagai pemilih muda yang diidentifikasikan berada pada rentang usia 17-25 tahun. Jumlah pemilih muda yang relative besar dianggap sebagai faktor penentu partisipasi politik di Indonesia. Menurut Direktur Eksekutif Saiful Muzani Research and Consulting (SMRC), Djayadi Hanan, 
prosentase pemilih muda dalam Pemilihan Kepala Daerah DKI Jakarta pada bulan Juni-Juli lalu 2017 mencapai 25\%. Prosentase ini cukup signifikan dalam mempengaruhi perolehan suara. Sementara itu di Tulungagung jumlah pemilih pemula pada pemilihan gubernur lalu mencapai sekitar 5\% dari total Daftar Pemilih Tetap ${ }^{1}$. Jumlah ini cukup potensial bagi para kandidat dalam menjaring dukungan.

Pemilih muda dinilai memiliki kemampuan menelaah konten dan keaktifan politik yang unik. Mereka memiliki cara sendiri dalam menjangkau informasi tentang kandidat kepala daerah. Pemilih muda juga dinilai kritis dalam merespon isu-isu perpolitikan.Untuk itu banyak pihak berupaya memaksimalkan potensi besar tersebut dengan memberikan perhatian yang lebih.Sosial media juga memiliki peran vital dalam mempengaruhi pola memilih kalangan muda. Konsumsi generasi muda Indonesia terhadap sosial media termasuk yang tertinggi di dunia. Indonesia menduduki peringkat kelima akun Twitter terbanyak di dunia. Pengguna Twitter ini didominasi oleh para generasi muda, yang merupakan potensi pemilih muda.

Media Sosial mendukung adanya interaksi social yang memiliki fungsi, peran dan dampak bagi kehidupan masyarakat. Facebook, Twitter, YouTube dapat menjadi instrument baru dalam diseminasi informasi politik tentang pemilu dan kandidat. Media sosial dapat dimanfaatkan dalam proses pembentukan opini tentang kesadaran partisipasi politik, kandidat, proses pemilihan umum dan penyampaian program kerja pasangan calon pada masa kampanye. Media sosial menjadi lokasi akurat untuk memberitakan isu-isu politik yang sedang terjadi menjadi bahasan menarik. Hasil diskurs ini pun dapat dilihat langsung melalui trending topic, jumlah hashtag atau tagar dan unggahan yang dilakukan oleh warganet ${ }^{2}$. Keberadaan media sosial ini juga membangun kedekatan antara publik dengan dengan pemilihnya. Para pemilih muda yang memiliki paparan media sosial tinggi juga mencari informasi ketokohan dan membangun kepercayaan dari media sosial. Walikota Bandung Ridwan Kamil menjadi tokoh yang mampu menarik simpati publik dan generasi muda melalui bantuan media sosial. Ridwan Kamil memiliki jumlah pengikut pada akun sebesar sebanyak 8,8 juta akun instagram, twitter sebanyak 3,1 juta pengikut, dan 3,3 juta pengikut pada akun Facebook. Ridwan Kamil secara aktif menyapa masyarakat, menyampaikan ide-ide serta kegiatan-kegiatan politik bahkan humor segar di akun media sosialnya. Langkah ini sebagai upaya membangun kepercayaan publik yang berpotensi menjadi pemilih dalam kontestasi pemilihan kepada daerah. Bagi para pemilih muda, data dan informasi digital ini yang menjadi petunjuk dan mempengaruhi cara mereka dalam menilai sebuah proses politik hingga kandidat.

Pemilih muda di kabupaten Tulungagung juga memiliki paparan media baru yang cukup tinggi.Tingkat konsumsi media sosial pemilih muda di kabupaten Tulungagung juga tinggi. Fenomena ini terlihat dari maraknya akun akun media social local yang membangun diskursus secara daring. Tulisan ini ingin melihat terlebih dahulu penggunaan unggahan pada media sosial untuk meningkatkan partisipasi pemilih. Selanjutnya untuk melihat motivasi memilih dan intensitas ketertarikan pemilih muda pada konten konten politik dan pemilihan umum kepala daerah di Kabupaten Tulungagung. Dalam tulisan ini menggunakan dua objek untuk mendapatkan hasil komprehensif tentang pemilih pemuda, sosial media dan partisipasi politik di Kabupaten Tulungagung. Pertama, penelitian ini menggunakan unggahan unggahan yang telah dibuat sedemikian rupa untuk melihat interaktifitas pemilih. Dua, data juga didapatkan melakukan survey yang dilakukan sesaat setelah pemilih muda keluar dari tempat pemungutan suara. Survey ini dilakukan untuk memberikan gambaran umum tentang paparan media sosial, pola komunikasi dan partisipasi pemilih muda di Kabupaten Tulungagung.

${ }^{1}$ DISKOMINFO Kabupaten Tulungagung. 2018. ' Pendidikan Politikl bagi Pemilih Pemula' dipublikasikan pada http://tulungagung.go.id/?p=5507 diakses pada 5 mei 2018.

${ }^{2}$ Gayatri, H Irine. LIPI.(Edisi 17 Desember 2012).Kekuatan Media Sosial dalam Pembentukan Opini Politik. Sumber: http://www.politik.lipi.go.id/in/kolom/politik-nasional/753-kekuatan-media-sosial-dalam-pembentukan-opini-politik-.html. 


\section{Kajian Pustaka}

\section{A. Media Sosial dan Politik di Indonesia}

Salah satu teori Komunikasi yang menjelaskan mengenai perubahan media adalah teori Difusi Inovasi. Teori ini mengatakan komunikator yang mendapatkan pesan dari media massa sangat kuat untuk mempengaruhi orang-orang. Dengan demikian, adanya inovasi (penemuan), lalu disebarkan (difusi) melalui media massa akan kuat memengaruhi massa untuk mengikuti. ${ }^{3}$ Rogers dan Shoemaker (1971) menyebutkan difusi adalah proses dimana penemuan disebarkan kepada masyarakat yang menjadi anggota sistem sosial. Teori ini di awal perkembangannya mendudukkan peran pemimpin opini (opinion leader) dalam memengaruhi sikap dan perilaku masyarakat. Hal ini berarti Teori difusi - inovasi memposisikan peran media massa sebagai agen perubahan sosial dengan pengaruh kuat di masyarakat. Hal atau sesuatu yang baru akan menimbulkan keingintahuan masyarakat dan cenderung untuk menyebarkan kepada orang lain. Lalu, media massa berperan untuk memperkenalkan penemuan baru tersebut. ${ }^{4}$

Pengaruh media sosial dalam dunia politik khususnya dalam hal komunikasi politik, terutama dalam kampanye Pemilu. ${ }^{5}$ Penting bagi institusi politik untuk berpartisipasi aktif dalam komunikasi politik yang berbasiskan media sosial, terutama dalam kampanye Pemilu. Media sosial selanjutnya menggambarkan sebagai sarana ideal dan basis informasi untuk mengetahui opini publik tentang kebijakan dan posisi politik, selain untuk membangun dukungan komunitas kepada politisi yang tengah berkampanye. Sejumlah penelitian menunjukkan politisi di seluruh dunia telah mengadopsi media sosial untuk menjalin hubungan dengan konstituen, berdialog langsung dengan masyarakat dan membentuk diskusi politik. Kemampuan menciptakan ruang dialog antara politisi dengan publik serta menarik minat pemilih pemula/pemilih muda membuat media sosial semakin penting bagi politisi. ${ }^{6}$

Internet diharapkan bisa menjadi media bagi mengalirnya informasi dua arah yang interaktif antara politisi dan pendukungnya.Internet memberikan forum yang seluas-luasnya bagi pengembangan kelompok kepentingan dan sebagai sarana penyaluran opini. ${ }^{7}$ Pada Pemilu 2004 dan 2009 penggunaan internet semakin meningkat pada partai politik, individu calon legislator, calon presiden dan calon wakil presiden. ${ }^{8}$ Keberhasilan menggunakan media sosial dipandang sebagai salah satu faktor kesuksesan Barack Obama memenangi pemilihan presiden Amerika Serikat. Sekitar 30 persen pesan-pesan kampanye Obama disampaikan melalui media baru. ${ }^{9}$

Media sosial merupakan rimba raya, dan praktis tidak ada peraturan di dalamnya. ${ }^{10}$ Media sosial telah mengaburkan pemahaman orang, apakah yang dikatakan tersebut merupakan sikap resmi atau hanya ungkapan pemikiran atau perasaan dia sebagai pribadi. Sikap resmi atau institutional rhetoric dan ungkapan pribadi atau everyday talk sering tumpang tindih. ${ }^{11}$ Seseorang akan salah persepsi apakah curhat yang dilakukan oleh aktor politik di media sosial merupakan ungkapan dirinya sebagai pribadi atau mewakili institusinya. Persoalannya aktor politik di Indonesia masih belum menyadari bahwa dalam berkomunikasi di media sosial memerlukan kemampuan tersendiri. Kemampuan di sini tentu tidak hanya kemampuan teknis, tetapi

\footnotetext{
${ }^{3}$ Nurudin, Pengantar Komunikasi Massa, (Depok: Raja Grafindo Persada, 2013), Hal. 189

${ }^{4}$ Ibid. Hal. 190-191.

${ }^{5}$ Chavez, 2012; Riaz, 2010; Stietglitz \& Dang-Xuan, 2012.

${ }^{6}$ Stieglitz \& Dang-Xuan, 2012.

${ }^{7}$ Asih, Irsanti Widuri. 2011. “Media Sosial dan Politik: Sarana E-Democracy atau Sekadar Pepesan Kosong?”dalam Proceeding Semnas FISIPUT. Hal.452-465.

${ }^{8}$ Putra, Afdal Makkuraga. 2011. "Media Baru dan Fenomena Komunikasi Politik pada Pemilukada di Propinsi Banten 2011" dalam Jurnal UMN Volume III Nomor 2 Desember. Hal.23-34.

${ }^{9}$ Riaz, Saqib. 2010. "Effects on New Media Technologies on Political Communication" dalam Journal of Political Studies, Vol. 1, Issue 2 University of the Punjab Lahore. Hal. 161-173.

${ }^{10}$ Fitch, Kate. 2009. "Making Friends in the Wild West: Singaporean Public Relations Practitioners' Perceptions of Working in Social Media" dalam PRism 6(2). Hal 1-14.

${ }^{11}$ Finet, Dayna. 2001. "Sociopolitical Environments and Issues" dalam The New Handbook of

Organizational Communication: Advances in Theory, Research, and Methods. Fredric M. Jablin \& Linda L. Putnam (Eds). Thousand Oaks: SAGE. Hal 274-276.
} 
mentalitas.Kehadiran media sosial menuntut para pelaku politik untuk beradaptasi. Namun para pelaku politik tersebut sering kesulitan dalam fase adaptasi ini ${ }^{12}$. Politisi dan partai politik sekadar latah menggunakan jejaring sosial untuk berinteraksi. Media sosial masih dimanfaatkan sebagai media kampanye, belum interaktif, belum aspiratif. Padahal media sosial memiliki potensi sebagai sarana untuk mendengarkan suara masyarakat. ${ }^{13} \mathrm{Di}$ era interaktif digital, produksi pesan dan citra politik malah justru menjadi hal yang rawan untuk "diganggu". Ada kecenderungan di masa kampanye Pemilu, internet justru digunakan untuk mengolok-olok politisi dan menyerang politisi yang tidak disukai. ${ }^{14}$

Kesuksesan branding melalui media sosial ditentukan oleh pengelolaan media sosial secara up to date dan senantiasa menjaga komunikasi secara konsisten dengan menggunakan struktur percakapan yang sedang berkembang dalam lingkungan masyarakat. ${ }^{15}$ Berdasarkan penelitian yang berkembang, penggunaan media sosial mempunyai beberapa keuntungan strategis. Secara garis besar keuntungan yang dihasilkan dari branding menggunakan media berbasis internet adalah mudah, murah, praktis, dan efektif. ${ }^{16}$ Politisi tentu merasa menghadapi tantangan lain terkait penggunaan media sosial sebagai upaya pembentukan branding yakni menampilkan pribadi sesuai dengan harapan masyarakat. ${ }^{17}$

\section{B. Partisipasi Politik Pemilih Muda}

Para pemilih pemula atau dikhususkan lagi para pemilih muda perlu didorong memiliki kemauan terlibat dalam berpolitik atau dengan kata lain berpartisipasi politik. Partisipasi politik sendiri adalah kegiatan seseorang atau kelompok orang untuk ikut serta secara aktif dalam kehidupan politik, yaitu dengan jalan memilih pimpinan Negara dan, secara langsung atau tidak langsung, mempengaruhi kebijakan pemerintah (public policy).Salah satu aktivitas partisipasi politik mencakup tindakan seperti memberikan suara dalam pemilihan umum, menghadiri rapat umum, menjadi anggota suatu partai atau kelompok kepentingan, mengadakan hubungan (contacting) dengan pejabat pemerintahan atau anggota parlemen, dan sebagainya. ${ }^{18}$

Di dalam negara demokrasi, tingginya tingkat partisipasi politik menunjukkan bahwa warga negara mengikuti dan memahami masalah politik dan ingin melibatkan diri dalam kegiatankegiatan itu. Sebaliknya tingkat partisipasi yang rendah pada umumnya dianggap sebagai tanda yang kurang baik, karena berarti bahwa banyak warga negara tidak menaruh perhatian terhadap masalah ketatanegaraan. Rendahnya partisipasi politik salah satuya diakibatkan oleh rendahnya kesadaran politik masyarakat, terutama kalangan anak muda.Pengertian "Pemuda" menurut UU No. 40 tahun 2009 tentang kepemudaan. Pengertian "Pemuda" adalah warga negara Indonesia memasuki periode penting pertumbuhan dan perkembangan berusia 16 (enam belas) sampai 30 (tiga puluh) tahun. Sedangkan pengertian "Kepemudaan" adalah berbagai hal berkaitan dengan potensi, tanggung jawab, hak, karakter, kapasitas, aktualisasi diri, dan cita-cita pemuda.

Jadi, pemilih muda adalah mereka yang berusia 17-29 tahun pada hari pencoblosan atau yang sudah menikah dan tercatat dalam daftar pemilih tetap. Pemilih muda dalam setiap pemilu nasional ataupun pemilukada mempunyai jumlah yang relatif besar. Miriam Budiarjo secara umum mengartikan partisipasi politik sebagai kegiatan sesorang atau kelompok orang untuk ikut serta secara aktif dalam kehidupan politik yaitu dengan jalan memilih pimpinan negara secara langsung atau tidak langsung memengaruhi kebijakan pemerinah (public policy). ${ }^{19}$

\footnotetext{
${ }^{12}$ Chavez, 2012.Op cit.

${ }^{13}$ Asih, Irsanti Widuri. 2011. "Media Sosial dan Politik: Sarana E-Democracy atau Sekadar Pepesan Kosong?" dalam Proceeding Semnas FISIPUT. Hal.452-465.

${ }^{14}$ Momoc, Antonio. 2011. "New Media and Social Media in the Political Communication" dalam The 6th Edition of The International Conference European Integration-Realities and Perspectives. Hal.556- 562.

${ }^{15}$ Lipiainen, Heini dan Karjaluotto, Heikki. 2012. "Suggestions For B2B Brand On Surviving In The Digital Age.” Journal University of Helsinki.Vol 3.Hal. 1-6.

${ }^{16}$ Anshari, 2013.Op cit.

${ }^{17}$ Guervitch, et.al., 2009. Op cit.

${ }^{18}$ Mirriam, 1998.Op cit.

${ }^{19}$ Sastroatmodjo, Sudijono. 1995. Perilaku Politik. Semarang: Ikip Semarang Press. Hal. 68.
} 
Terakhir menurut Keith Faulks partisipasi politik adalah keterlibatan aktif individu maupun kelompok dalam proses pemerintahan yang berdampak pada kehidupan mereka. Hal ini meliputi keterlibatan dalam pembuatan keputusan maupun aksi oposisi, yangpenting partisipasi merupakan proses aktif. $^{20}$

Menurut Ramlan Surbakti partisipasi politik terbagi menjadi dua yaitu partisipasi aktif dan pasrtisipasi pasif. Partisipasi aktif adalah mengajukan usul mengenai suatu kebijakan umum, mengajukan alternatif kebijakan umum yang berlainan dengan kebijakan yang dibuat pemerintah, mengajukan kritik dan perbaikan untuk meluruskan kebijakan, membayar pajak dan memilih pemimpin pemerintah. Sebaliknya, kegiatan yang termasuk dalam kategori partisipasi pasif berupa kegiatan-kegiatan yang menaati pemerintah, menerima, dan melaksanakan saja setiap keputusan pemerintah. ${ }^{21}$ Sementara itu, Milbart dan Goel membedakan partisipasi menjadi beberapa kategori. Pertama, apatis, artinya, orang yang tidak berpartisipasi dan menarik diri dari proses politik. Kedua, spectator, artinya, orang yang setidak-tidaknya pernah ikut memilih dalam pemilihan umum. Ketiga, gladiator, artinya mereka yang secara aktif terlibat dalam proses politik, yakni komunikator, spesialis mengadakan kontak tatap muka, aktivis partai dan pekerja kampanye, dan aktivis masyarakat. ${ }^{22}$ Dari artikel yang diterbitkan KPU Jakarta disebutkan sebagian dari pemilih muda adalah pemilih pemula, yaitu warganegara yang berusia 17-21 tahun dan baru pertama kali memilih dalam pemilu.Untuk meningkatkan partisipasi dalam pemilu pemilih muda perlu mengetahui dan memahami berbagai hal yang terkait dengan pemilu. ${ }^{23}$

\section{Metodologi Penelitian}

Penelitian ini dibuat menggunakan paradigma kualitatif yang diperkuat dengan data kuantitatif. Paradigma kualitatif digunakan untuk menelisik sebuah fenomena secara mendalam. Fenomena yang ditelusuri secara kualitatif dalam penelitian ini adalah konten informasi pada akun sosial media atau postingan yang dinilai efektif untuk membantu meningkatkan pertisipasi pemilih muda di Kabupaten Tulungagung. Sedangkan data kuantitatif digunakan untuk memperkuat data kualitatif yang telah ditemukan sebelumnya. Data kuantitatif tersebut digunakan untuk mendapatkan gambaran umum tentang kondisi pemilih muda dan perilaku memilih mereka. Pada penelitian ini data kuantitatif digunakan untuk melihat ketertarikan, intensitas dan interaksi para pemilih muda atas konten informasi atau postingan yang berhubungan dengan politik dan pilkada di Tulungagung.

Objek dalam penelitian ini dibagi menjadi dua. Pertama objek penelitian kualitatif berupa konten informasi atau posting yang dilakukan di akun social media yang telah dilakukan sebelumnya. Konten ini telah di posting di masa Pemilukada tulungaggung tahun 2018. Konten informasi atau postingan dipilih berdasarkan kriteria yang telah ditentukan. Sedangkan objek dari survey adalah pemilih muda atau pemula yang baru saja memberikan suaranya dalam pilkada.

Pemilihan objek pada metode penelitian kualitatif dilakukan untuk mereduksi banyaknya unggahan atau postingan yang terdapat dalam akun media social yang telah dibuat. Konten informasi di social media yang akan dianalisis dilakukan dengan memilih konten berdasarkan jumlah like, comment maupun share. Jumlah like, comment maupun share ini merupakan representasi dari interaktivitas dari user. Banyaknya jumlah like, comment maupun share sekaligus menunjukkan bahwa konten tersebut disukai oleh para warganet. Pemilihan data tidak diperlukan untuk analisa kuantitatif.

Teknik Analisa Data dilakukan dalam dua cara. Analisa data pertama dilakukan dengan melakukan analisis terhadap konten informasi atau posting yang ada di media social. Konten yang paling banyak disukai oleh warga net tersebut dianalisa secara deskriptif. Adapun yang dianalisa

\footnotetext{
${ }^{20}$ Faulks, Keith. 2010. Sosiologi Politik. Bandung: Nusa Media.Hal.226.

${ }^{21}$ Surbakti, Ramlan. 1997. Partai Pemilu dan Demokrasi . Yogyakarta: Pustaka Pelajar. Hal 142.

22 Ibid. Hal. 143.

${ }^{23}$ Sumber: http://www.kpu.go.id, 14 Maret 2014, 17.06 WIB
} 
adalah isi dari konten dan keunikan konten tersebut. Hasil Analisa ini sekaligus dapat menunjukkan kecenderungan informasi yang disukai oleh warganet yang berhubungan dengan pilkada dan politik.

Teknik Analisa kedua dilakukan pada data kuantitatif yang menjadi penguat penelitian ini. Data kuantitatif tersebut di dapat dari hasil survey yang dilakukan saat hari pencoblosan. Hasil kuesioner yang diisi oleh responden tersebut kemudian dilakukan perhitungan dengan perhitungan statistic. Hasil perhitungan statistic selanjutnya dilakukan Analisa secara deskriptif. Hasil perhitungan tersebut kemudian dianalisa untuk dibaca sebagai sebuah fenomena yang terjadi di ranah pemilih di Kabupaten Tulungagung

\section{Penyajian dan Analisis Data}

\section{A. Analisis Unggahan Media Sosial dan Partisipasi Politik Pemilih Muda Kabupaten ulungagung}

Selain bertanya kepada para responden, penelitian ini juga membuat sejumlah akun media Sosial. Akun media Sosial ini dibuat untukk melihat aktivitas warga net yang notabene generasi muda secara lebih komprehensif. Media Sosial yang dibuat ini akan dilihat interaktivitas dalam akun tersebut. Interaktivitas itu dilihat mulai dari pertumbuhan jumlah pertemuan maupun pengikut, unggahan konten informasi, interaksi yang tercipta dalam sebuah konten informasi yang diunggah. Ada dua akun yang dibuat pada dua platform berbeda. Akun pertama adalah 'Ayo Nyoblos' yang dibuat pada platform Facebook. Akun Kedua adalah @politiksehatanak yang betjalan pada platform Instagram.Instagram Dan Facebook dipilih Karena keduanya merupakan media Sosial yang banyak digunakan oleh masyarakat Indonesia khususnya tulungagung. Dua akun ini dibuat pada bulan JJunisebelum dimulai proses pemilihan umum dan masih aktif hingga saat ini.

Berdasarkan hasil analisa pada kedua akun media sosial yang sengaja dibuat selama proses pemilihan umum terlihat jika trend masyarakat dalam bermedia sosial telah bergeser. Publik tulungagung cenderung berubah dari menggunakan Facebook menjadi pengguna aktif Instagram yang terlihat dari pesatnya Jumlah pengguna instagram yang menyukai akun tersebut. Dari data kedua akun social media yang dibuat, akun facebook hanya disukai oleh 59 akun lain. Sedangkan Instagram disukai oleh 4253 akun lain. Jumlah ini terdiri dari perorangan, Lembaga dan sejumlah media local di Tulungagung terpantau ikut menyukai akun ini. Hal ini menunjukkan telah terjadi pergeseran pola komunikasi di ranah daring dari yang awalnya menggunakan facebook ke Instagram. Dari pertumbuhan jumlah akun ini sekaligus dapat disimpulkan Ada usaha dari masyarakat tulungagung untuk mencari informasi tentang politik melalui media sosial. Instagram adalah platform media sosial yang disukai untuk mencari informasi tentang preferensi politik. Hal ini relevan drngan hasil survey dimana pemilihan pemula tulungagung menyukai dan mencari informasi preferensi politiknya melalui media sosial.Ini terlihat dari sejumlah pertanyaan survey tentang kesukaan mereka mengikuti perdebatan atau tidak mengikuti melalui media sosial.
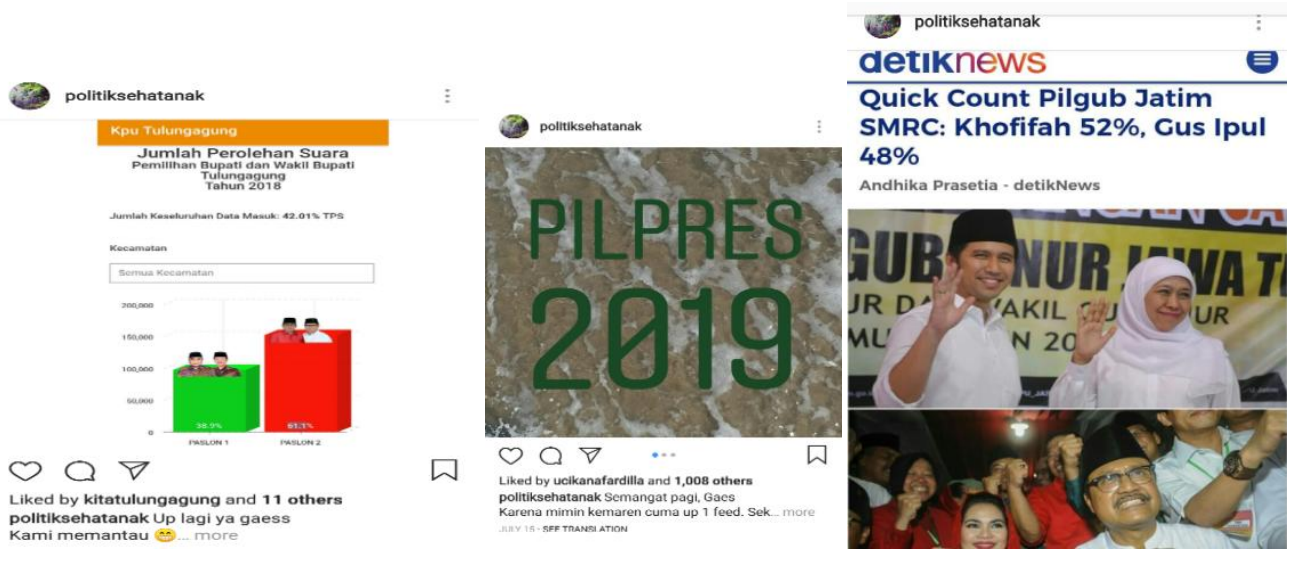

Fig. 1. Akun Instagram 
Penelitian ini juga melihat jenis unggahan seperti apa yang disukai oleh warga net yang notabene adalah pemilih muda. Gambar diatas merupakan konten informasi yang diunggah ke akun media sosial dalam penelitian ini. Informasi yang sama diunggah untuk dua akun sekaligus. Konten informasi tersebut adalah yang memiliki interaktivitas terbesar dalam pemilihan ini. Ada tiga konten informasi pada unggahan diatas. Ketiganya memiliki jumlah interaktivitas berupa likes dan komen terbanyak. Dua dari tiga konten tersebut berisi tentang informasi di politik dengan lingkup berbeda. Jumlah interaktivitas terbanyak terlihat pada konten konten nasional. Disusul dengan konten di lingkup provinsi dan terakhir adalah konten lokal Tulungagung sendiri. Artinya keinginan masyarakat tulungagung untuk mencari informasi politik itu besar. Namun besarnya keiginan tersebut hanya untuk konten informasi yang sudah banyak mereka ketahui sebelumnya. Dalam penelitian ini terlihat dari jumlah interaktivitas yang tinggi untuk konten nasional dan provinsi. Sedangkan untuk konten konten lokal mereka belum terlalu peduli. Hal ini bisa disebabkan minimnya informasi politik local yang menyediakan informasi untuk mereka akses.

\section{B. Ketertarikan Memilih Pemilih Muda di Tulungagung}

Penelitian ini ingin mendapatkan gambaran bagaimana ketertarikan pemilih muda pada proses pemilu. Responden akan diberikan pertanyaan apakah ketertarikan mereka hanya mengikuti trend atau tidak. Partisipasi yang hanya mengikuti trend dapat diartikan kesadaran pemilih muda untuk menyampaikan suaranya masih minim. Selanjutnya responden juga akan ditanya apakah ada faktor eksternal yang membuat dirinya berpartisipasi. Faktor eksternal itu dapat berupa ajakan maupun paksaan dari pihak luar dirinya.Pihak luar dalam penelitian ini adalah keluarganya, pasangan, sahabat, atasan, kerabat.Faktor eksternal ini penting untuk diketahui untuk menggambarkan apakah ketertarikan lebih dominant dari dalam atau luar diri pemilih muda.Tingkat Kesenangan pemilih muda dalam berpartisipasi bisa menggambarkan apakah Ada kesadaran pentingnya ikut serta dalam pemilu atau tidak.Penelitian ini juga ingin melihat adakah budaya komunal di kalangan pemilih muda yang berpartisipasi.

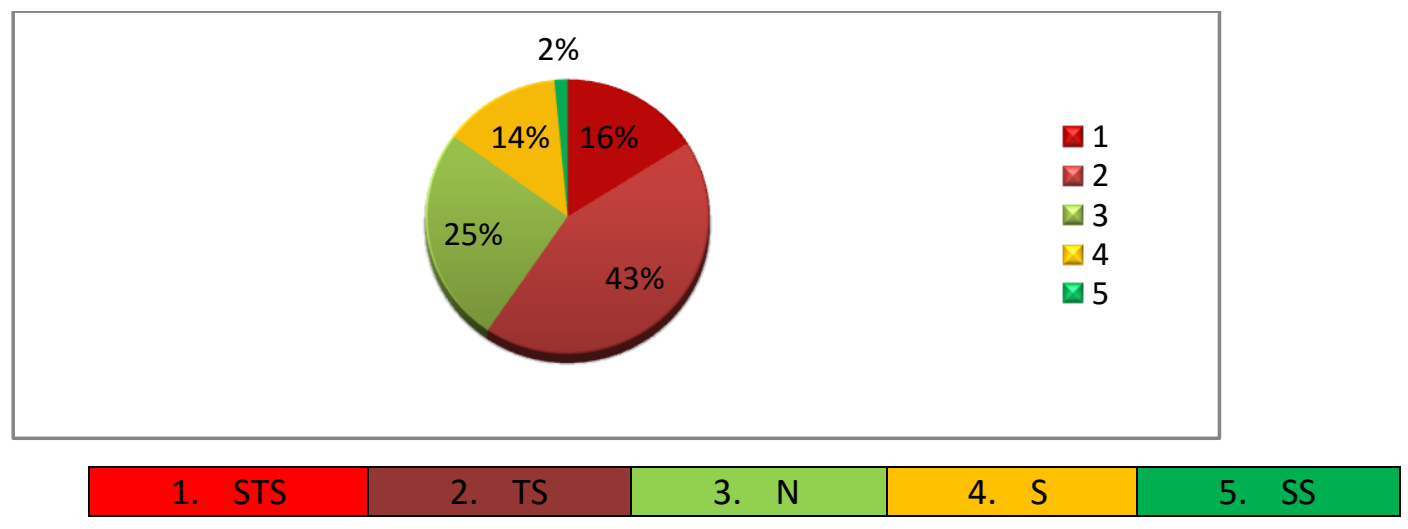

Fig. 2. Chart ketertarikan pemilih

Penelitian ini juga ingin melihat ketertarikan pemilih muda dalam mengikuti pilkada. Responden dalam penelitian ini juga ditanya tentang apakah partisipasi mereka hanya sebatas mengikuti tren? Responden penelitian ini mayoritas menjawab sangat tidak setuju.Yakni $43 \%$ dari responden menjawab sangat tidak setuju.Sementara itu ada $16 \%$ responden yang menjawab tidak setuju. Hasil survey ini menunjukkan jika mayoritas pemilih yang menjadi responden datang ke TPS untuk memberikan suara tidak karena ikut ikutan atau trend untuk ikut pilkada semata. Ada satu hal yang harus dicermati dari penelitian ini yakni munculnya hasil netral dari survey ini.Sebanyak $25 \%$ responden menyatakan netral atau mereka tidak menyetujui datang ke TPS mengikuti trend atau tidak.Hal ini menunjukkan jika pemilih yang menjadi responden dan memilih netral dalam survey ini sebenarnya belum mengetahui mengapa dia harus berangkat ke TPS.

Kesadaran pemilih muda untuk datang ke TPS pun juga sudah bagus. Hal ini terlihat dari 39\% dan $12 \%$ responden dalam survey ini yang menyatakan sangat tidak setuju dan tidak setuju, 
ketertarikan datang ke TPS merupakan ajakan pihak eksterna. Pihak eksternal dalam penelitian ini berasal dari banyak entitas seperti keluarga, pasangan, teman, kerabat, dan atasan. Namun fakta lain yang tidak dapat dinafikan adalah keterlibatan unsur eksternal yang sudah disebutkan diatas dalam mempengaruhi ketertarikan pemilih muda untuk memberikan suaranya. Sebanyak $18 \%$ dan $8 \%$ responden menyatakan setuju dan sangat setuju bahwa kedatangannya ke TPS Karena ajakan pihak eksternal. Yakni keluarga, pasangan, teman, kerabat, atasan. Hal ini sekaligus menunjukkan pendidikan politik bagi pemilih muda bisa dilakukan oleh entitas entitas eksternal tersebut. Terbukti Hal ini bisa memobilisasi pemilih muda untuk datang ke TPS. Jika kita jabarkan lebih lanjut, Hal ini juga berhubungan dengan cara komunikasi dan penanaman pemahaman tentang pentingnya memilih. Melihat kecenderungan ini, sekaligus bisa menjadi masukan bagi KPU Tulungagung terkait sosialisasi pemilu dan pilkada.Sosialisasi pemilu dan pilkada harus dilaksanakan secara setara dan Massif. Sebab berdasarkan data ini Ada ketetkaitan antara keinginan memilih dengan peran unsur eksternal.

Pemilih pemula di Kabupaten Tulungagung berpertisipasi dalam pilkada serentak 2018 bukan karena adanya paksaan dari pihak lain. Sebanyak 22\% dan 55\% responden dalam penelitian ini menyatakan tidak setuju Dan sangat tidak setuju jika kehadirannya di TPS akibat paksaan pihak eksternal.Hasil ini memperkuat hasil survey pada item sebelumnya jika kesadaran politik generasi muda Tulungagung sudah bagus.Hal ini dilihat dari hadirnya Pemilih muda bukan karena tren dan juga juga bukan paksaan.

Pemilih muda di Kabupaten Tulungagung mayoritas senang ikut serta dalam pemilihan umum. Sebanyak 58\% Dan 12\% responden menyatakan setuju dan sangat setuju saat ditanya apakah mereka senang ikut berpertisipasi dalam pemilihan umum. Data ini sekaligus menjadi modal bahwa regenerasi proses demokrasi masih akan terus berlanjut. Tingginya jumlah responden yang senang telah berpertisipasi dalam pemilu ini menunjukkan animo Pemilih pemula pada proses demokrasi di level daerah dan kota kecil sebenanrnya sangat besar. KPU dan partai politik seharusnya mampu menangkap ini sebagai potensi dalam melakukan pendidikan politik untuk proses demokrasi yang lebih baik.

Secara kultural kehidupan masyarakat daerah identik dengan budaya komunal yang tinggi.Mereka gemar berkumpul dengan sesama dalam sebuah komunitas masing masing. Budaya komunal ini agaknya juga terbawa sampai pada peoses demokrasi yang dialami oleh pemilih muda di Kabupaten Tulungagung. Sebanyak 56\% Dan 11\% responden menyatakan senang dan senang sekali berpartisipasi memilih bersama teman teman. Data ini sekaligus menjawab penyebab ajakan pihak eksternal untuk memberikan suara bagi pemilih muda. Rekan sebaya merupakan alasan mereka yang menjawab datang ke TPS karena ajakan pihak eksternal. Hal ini sekaligus dapat menjadi masukan Cara untuk mendekati para pemilih muda.Pendidikan politik berbasis komunitas menjadi Cara jitu untuk membantu disseminasi informasi tentang pemilu dan demokrasi bagi pemilih pemula di Tulungagung.

\section{Pemilih Muda dan Aktivitas di Media Sosial}

Pemilih muda merupakan generasi muda dengan paparan internet tinggi.Moment pemilu juga menjadi saat untuk menjadikan setiap aktivitas yang berhubungan dengan pemiliknya menjadi viral. Perilaku ini tidak hanya ditunjukkan oleh kalangan elit politik namun juga masyarakat. Generasi muda identik dengan perilaku memviralkan sesuatu. Penelitian ini ingin mendapatkan gambaran apakah Ada motif dari pemilih muda untuk menjadi viral dengan berpartisipasi atau tidak. Memviralkan aktivitas memilih ini menjadi wujud aktualisasi diri yang dilakukan oleh generasi muda. Tujuan memviralkan aktivitas politik melalui media sosial membuat generasi muda ingin diakui telah ikut serta dalam aktivitas pesta demokrasi lima tahunan. Selain menjadikan aktivitas politik sebagai gerakan viral atau trending, penelitian ini ingin mendapatkan gambaran tentang diskursus politik yang dibangun pemilih muda melalui media sosial. Hal ini untuk mendapatkan gambaran apakah terbangun sebuah sphere perpolitikan yang baik di media sosial oleh generasi muda. 


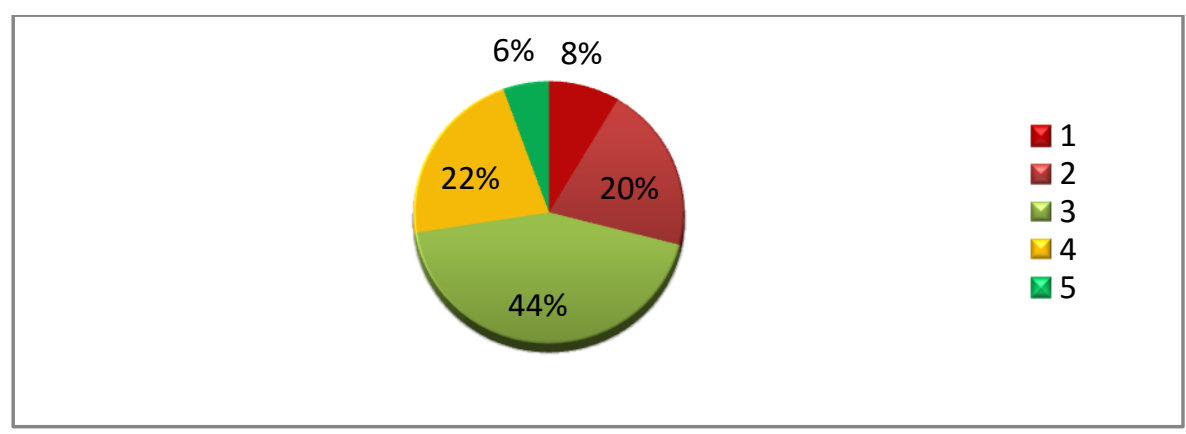

Fig. 3. Chart partisipasi Pemilu

Pada saat pemilihan umum banyak unggahan di media daring maupun akun media sosial tentang trending topik pemilu di sosial media. Beragam cara dilakukan untuk menunjukkan euphoria tersebut. Ketika ditanya apakah pemilih muda di tulungagung terlibat dalam budaya menjadikan gerakan trending topic saat berpartisipasi dalam pemilu? Sebanyak $44 \%$ responden memilih untuk mengambil posisi netral. Jumlah ini sekaligus menjadi yang terbanyak. Hal ini menunjukkan jika mayoritas pemilih muda di tulungagung tidak terpengaruh untuk menjadikan proses memilihnya sebagai sebuah gerakan viral. Namun jumlah dari yang senang dan tidak senang pun relatif berimbang.

Hasil yang Tak jauh berbeda juga terlihat pada kegemaran Pemilih muda dalam membahas partisipasi pemilu di media Sosial.Sebanyak $48 \%$ responden juga memilih posisi netral. Jumlah ini sekaligus menjadi posisi yang terbanyak. Artinya Pemilih pemula di kabupaten Tulungagung menggunakan media sosial untuk keperluan lain. Sedangkan jumlah responden yang menyatakan tidak setuju dan sangat tidak setuju masing masing 9\% dan 25\%. Artinya Pemilih muda di Tulungagung tidak suka membahas partisipasi pemilu mereka di sosial media.

\section{Candidacy dan Ketidakpercayaan pada Proses Pemilih}

Candidacy merupakan istilah untuk menggambarkan seseorang yang terlibat dalam sebuah pemilihan. Candidacy erat kaitannya dengan ketokohan seorang calon ataupun pandangan calon. Penelitian ini ingin mendapatkan gambaran apakah candidacy menjadi salah satunya faktor penentu pemilih muda dalam berpartisipasi atau tidak. Candidacy disini dibagi dua menjadi kesukaan dan ketidakpedulian pada calon. Selain itu penelitian ini juga ingin melihat cara pandang pemilih muda pada hasil akhir pemilu. Penelitian ini ingin mendapatkan gambaran apakah pemilih muda mempertimbangkan masalah hasil akhir pemilu atau tidak dengan memantabkan skeptisan mereka pada hasil pemilu.

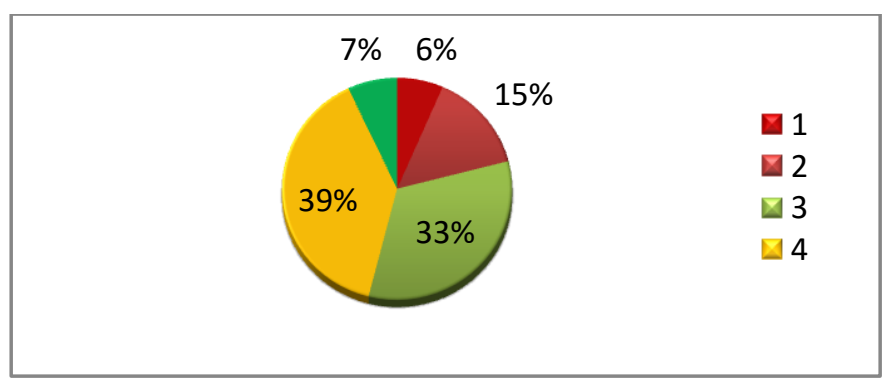

Fig. 4. Chart Ketokohan Kandidat

Ketokohan kandidat menjadi alasan mayoritas pemilih muda di Kabupaten Tulungagung berpertisipasi dalam pemiu.Sebanyak 39\% dan 7\% responden menyatakan setuju dan setuju sekali. Situasi ini menunjukkan pemilih pemula di Kabupaten Tulungagung memiliki kemampuan untuk mempelajari track record kandidat. Sebab sebuah preferensi politik berdasarkan ketokohan akan muncul ketika seseorang telah mempelajari kadidat.

Pemilih muda di Kabupaten Tulungagung selalu optimis pada hasil pemilu. Optomisme ini dapat diartikan mereka percaya apapun hasil pemilu merupakan hasil yang terbaik. Hal ini terlihat 
saat responden ditanya apakah pernah tidak berpartisipasi karena skeptis pada hasil pemilu. Sebanyak 16\% Dan 37\% menjawab tidak setuju dan sangat tidak setuju. Bahkan angka sangat tidak setuju ini sekaligus menjadi yang terbesar. Artinya pemilih muda di Tulungagung tetap akan memberikan hak pilihnya dan optimis pada apapun hasilnya. Hal ini menunjukkan kepercayaan pemilih muda bahwa pemilu di Tulungagung berlangsung sesuai dengan kaidah kaidah dan azas pemilihan umum.

Dibalik ketertarikannya untuk berpargisipasi pemilu karena ketokohan, rupanya pemilih muda di Tulungagung tidak mempedulikan apakah dia suka dengan pasangan calon atau tidak. Sebanyak 38\% responden menyatakan sangat tidak setuju pernah tidak berpertisipasi karena ada paslon yang tidak disukai. Pemilih muda di Kabupaten Tulungagung tetap akan memberikan suaranya di TPS walaupun ada pasangan calon yang tidak dia sukai. Artinya ada potensi undecided voters dan swing voters yang besar dari pemilih muda di kabupaten Tulungagung. Undecided voters dan swing voters ini biasanya menjadi indikator pemilih rasional. Maka para pemilih muda di kabupaten Tulungagung berpotensi untuk menjadi rational voters. Hal ini merupakan modal awal bagi keberlangsungan kualitas pemilu dan demokratisasi di Tulungagung.

\section{E. Partisipasi dan Proyeksi Masa Depan Kebangsaan}

Partisipasi publik menjadi poin penting dalam sebuah pemilihan umum. Partisipasi ini dapat menunjukan kepedulian dan kesadaran publik atas masa depan suatu bangsa. Tingkat partisipasi ini juga dapat menjadi proyeksi masa depan suatu bangsa. Penelitian ini ingin mendapatkan gambaran mulai dari kepedulian pemilih muda pada sistem pemerintahan.Hal ini ditunjukkan dengan partisipasi dari pemilih muda itu sendiri. Selain itu penelitian ini juga ingin memotret kesadaran pemilih muda bahwa pemilu berkorelasi dengan masa depan mereka selama konteks kehidupan berbangsa dan bernegara. Pada tataran yang lebih strategis penelitian ini juga ingin memotret partisipasi kalangan muda sebagai agen pengawasan kinerja pemerintah untuk masa depan Indonesia yang lebih baik. Bagaimanapun juga pemerintahan yang demokratis berasal dari rakyat, oleh rakyat dan untuk rakyat.Hal ini para tokoh yang dipilih untuk mewakili publik, dan membahas kepentingan publik. Sehingga urgensi pengawasan pun meningkat untuk menjamin publik mendapatkan hak hak mereka.

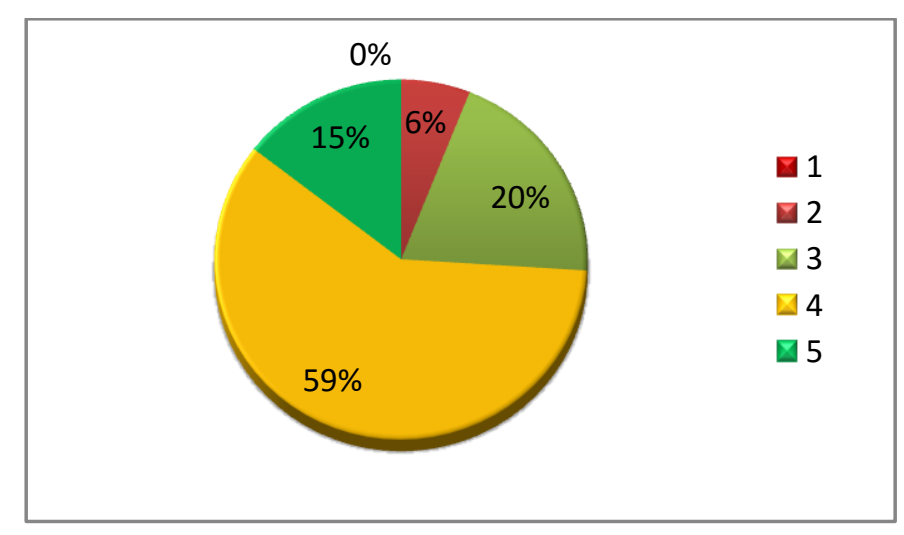

Fig. 5. Chart Kesadaran Partisipasi Pemilu

Kesadaran pentingnya berpartisipasi dalam pemilu juga terlihat saat para responden ditanya pemilu adalah bentuk kepedulian terhadap pemerintah. Sebanyak 59\% reponden setuju pada statement ini. Hal ini diperkuat juga dengan 14\% responden setuju sekali bahwa partisipasi dalam pemilu merupakan wujud kepedulian pada negara. Ini juga memperkuat bahwa ada kesadaran dan harapan atas proses demokrasi di Tulungagung dari para pemilihan muda.

Saat ditanya keterlibatan dalam pengawasan kerja pemerintah mayoritas responden memilih mengambil sikap netral. Sebanyak $48 \%$ responden memilih mengambil sikap netral.Hal ini menunjukan bahwa merekapun masih bingung dengan terminologi pemerintahan dan bentuk partisipasi publik dalam mengawasi kinerja pemerintah. Padahal sudah ada serangkaian aturan yang menunjukan bahwa publik berhak untuk tahu dan terlibat dalam proses pemerintahan. Data 
ini juga menunjukkan adanya potensi apatis dari masyarakat tentang jalannya roda pemerintahan oleh para generasi muda. Ada beberapa faktor yang bisa menjadi penyebab. Pertama, murni ketidaktahuan. Masyarakat tidak tahu baik disengaja maupun tidak. Minimnya publikasi juga bisa menjadi salah satu faktor penting ini. Dua, pemerintahan adalah bagian dari kaum elit. Anggapan semacam ini bisa muncul saat publik tidak pernah merasakan hadirnya negara dalam menyelesaikan permasalahan yang dihadapi.

Para pemilih muda di kabupaten Tulungagung juga telah sadar bahwa partisipasi dalam pemilu adalah kewajiban. Sebanyak 57\% responden menyatakan setuju. Jumlah ini menjadi yang terbesar. Jumlah terbesar kedua adalah responden yang menyatakan sangat setuju mencapai $25 \%$.

Para pemilih muda di kabupaten Tulungagung juga percaya bahwa pemilu merupakan hal penting bagi masa depan. Sebanyak 51\% responden menyatakan setuju dengan statement ini. Jumlah ini sekaligus menjadi yang terbanyak dalam poin ini. Hal ini diperkuat dengan jumlah responden yang menyatakan sangat setuju mencapai $18 \%$ dari total responden.

Pemilih muda di Tulungagung juga percaya bahwa partisopasi Pemilu berhubungan dengan masa depan mereka. Hal ini terungkap saat para responden ditanya tentang pernahkah merasa partisipasi pemilu tidak berhubungan dengan masa depan. Sebanyak 38\% responden menyatakan sangat tidak setuju. Jumlah ini diperkuat dengan sebanyak $17 \%$ responden menyatakan tidak setuju. Artinya mayoritas responden percaya jika partisopasi dalam Pemilu menentukan masa depan mereka. Hasil ini memperkuat pertanyaannya serupa yang diajukan sebelumnya dan kesadaran para pemilih muda bahwa partisipasi adalah bentuk kewajiban.

Generasi muda Tulungagung umumnya sudah menyadari bahwa ditangan merekalah proses demokrasi sehat berada. Pada survey ini, sebanyak $60 \%$ responden setuju bahwa pemilih muda menjadi penentu politik sehat. Jumlah ini diperkuat dengan $21 \%$ responden menyatakan hal yang sama.

\section{F. Media Baru dan Diskursus Pemilu Pemilih Muda}

Pengguna media baru di Indonesia identik dengan kalangan anak muda. Sejak perkembangan teknologi informasi dan komunikasi media barupun menyaru menjadi sebuah sphere yang digunakan untuk disseminasi informasi politik. Tak jarang media sosial menjadi ranah penciptaan diskursus tentang kandidat, sistem pemilihan, dan proses demokrasi itu sendiri. Melihat kecenderungan ini, penelitian ini ingin memotret bagaimana menagement atau keterlibatan pemilih muda pada proses politik seperti ini. Penelitian ini memotret keterlibatan pemilih muda pada perdebatan seputar kandidat. Poin ini untuk melihat adakah keinginan generasi muda untuk mempelajari secara lebih lanjut tentang kandidat pandangan calon yang berlaga dalam kontestasi pemilu.

Saat ditanya soal keterlibatan dalam perdebatan tentang pasangan calon melalui media sosial, mayoritas responden memilih mengambil langkah aman. Sebanyak 46\% responden memilih untuk mengambil posisi netral. Jumlah ini sekaligus menjadi jumlah terbesar pertama. Sedangkan responden yang menjawab sangat tidak setuju mencapai $28 \%$. Jumlah ini sekaligus menjadi yang terbesar kedua.

Pemilih muda di Tulungagung umumnya adalah pembaca aktif tentang perdebatan paslon.Sebanyak $31 \%$ responden menyatakan sangat tidak setuju saat ditanya apakah dirinya menjadi pembaca pasif perdebatan paslon pemilu. Hal ini menunjukan ada keinginan untuk mencari informasi tentang kandidat secara aktif oleh pemilih muda. Sehingga dapat disimpulkan pemilih muda di Tulungagung relatif aktif dalam mencari informasi kandidat. Namun dalam poin ini harus juga diperhatikan tingginya jumlah yang memilih berada oada posisi netral. Jumlah ini menjadi yang terbesar dengan $34 \%$ responden.

Pemilih muda di Tulungagung juga mengambil posisi netral saat ditanya apakah dia tidak menyukai mengikuti arus perdebatan politik di sosial media meskipun anda berpartisipasi dalam pemilu (Presiden/ Gubernur/ Bupati). Sebanyak 45\% dari responden mengambil posisi netral. Sedangkan jumlah yang sangat tidak setuju mencapai $23 \%$ dan setuju mencapai $21 \%$. Artinya 
jumlah yang menyukai arus perdebatan politik dikalangan pemilih muda kabupaten Tulungagung lebih besar.

Mengikuti arus perdebatan paslon di media sosial membutuhkan kedewasaan tersendiri. Maka dari itu responden juga ditanya pernahkah tidak menyukai arus perdebatan politik yang berdampak pada terlambatnya ikut partisipasi pemilu. Mayoritas respondenpun menjawab dengan memilih posisi netral. Sedangkan responden yang menyatakan sangat tidak setuju mencapai 33\% atau 33\% responden menyukai dan tetap berpartisipasi dalam pemilu tepat waktu.

Pertanyaan pertanyaan diatas dilontarkan untuk mengulik sisi personal responden terkait dengan ketertarikan pemilih muda dalam penciptaan diskursus pada proses pemilihan. Mayoritas responden memilih untuk berada pada posisi aman atau metral. Ada dua penyebab mengapa mereka memilih pada posisi aman. Pertama, mereka tidak tahu tentang proses perdebatan politik baik dalam ranah dalam jaringan maupun luar jaringan. Dua, keengganan untuk membuka hal privat terkait dengan sistem dan pandangan politik.

\section{Kesimpulan}

Pemilu merupakan proses panjang dalam mencari pemimpin yang tepat untuk memimpin suatu wilayah. Kepedulian pada proses pemilu disinyalir mampu mendorong tingkat partisipasi publik. Pemilih muda adalah pihak yang akan terlibat dalam proses pemilu ke depan. Pemilih muda di Kabupaten Tulungagung cenderung menyukai konten unggahan tentang perpolitikan di level yang lebih tinggi seperti provinsi dan nasional dibanding lokal Tulungagung. Paparan media sosial dan kesadaran atas partisipasi pemilih muda Tulungagung juga tinggi. Hal ini menunjukkan optimism dalam perkembangan demokrasi di Tulungagagung.

\section{DAFTAR PUSTAKA}

Andarningtyas, Natisha. (Senin, 6 Februari 2017 14:32 WIB).Ini pemimpin negara yang eksis di medsos.ANTARA. 2017.

Anshari, Faridhian. 2013. "Radio Streaming Sebagai Alternatif Corporate Branding. Studi Kasus Radio Streaming Elti Channel Sebagai Corporate Branding ELTI Yogyakarta Tahun 2012. Tesis Fakultas Ilmu Sosial dan Ilmu Politik, Jurusan Komunikasi. Program Pascasarjana Universitas Gadjah Mada, Yogyakarta.

Asih, Irsanti Widuri. 2011. "Media Sosial dan Politik: Sarana E-Democracy atau Sekadar Pepesan Kosong?" dalam Proceeding Semnas FISIPUT, hal.452-465.

Asih, Irsanti Widuri. Media Sosial dan Politik: Sarana E-Democracy atau Sekadar Pepesan Kosong?.Disajikan dalam Proceeding Semnas FISIPUT. 2011.

BPS.Proyeksi Penduduk Kabupaten Kota Provinsi Jawa Timur. Jakarta. 2015.

BPS. Proyeksi Penduduk, Mercusuar Pembangunan Negara. Sumber: https://www.bps.go.id/KegiatanLain/view/id/85.

Budiardjo, Miriam. 1998. Partisipasi dan Partai Politik. Jakarta: Edisi Revisi. Yayasan Obor Indonesia.

Bungin, Burhan. Sosiologi Komunikasi: Teori, Paradigma, dan Diskursus Teknologi Komunikasi di Masyarakat. Kencana, Jakarta. 2006.

Chavez, Jonathan. (Mei, 2012). \#Fail: The Misuse of Social Media in the 2012 US Presidential Campaign. Slide Presentation. Sumber: https://www.tcd.ie/policyinstitute/assets/pdf/PL_Chavez_March12.pdf. Didownload pada 20 September 2017.

D'Orazio, F. The future of social media research: or how to re-invent social media listening in 10 steps. Retrived January 26, 2016, from Pulsar: http://www.pulsarplatform.com/blog/author/francesco-dorazio/page/3/. 2013. 
Darmaningtyas.Sistem Politik Indonesia Kestabilan Peta Kekuatan Politik Dan Pembangunan. PT Raja Grafindao Persada,Jakarta. 2006.

Digital Policy Council.(Desember, 2012).World Leaders on Twitter Ranking Report. Sumber: http://www.digitaldaya.com/admin/modulos/galeria/pdfs/69/156_biqz7730.pdf. Didownload pada 20 September 2017.

Edwards, A., Housley, W., Williams, M., Sloan, L., \& Williams, M. Digital social research, social media and the sociological imagination: surrogacy, augmentation and re-orientation. International Journal of Social Research Methodology, 245-260. 2013.

Faulks, Keith. Sosiologi Politik. Bandung: Nusa Media. 2010.

Finet, Dayna. 2001. "Sociopolitical Environments and Issues" dalam The New Handbook of Organizational Communication: Advances in Theory, Research, and Methods. Fredric M. Jablin \& Linda L. Putnam (Eds). Thousand Oaks: SAGE.

Finet, Dayna. Sociopolitical Environments and Issues. The New Handbook of Organizational Communication: Advances in Theory, Research, and Methods. Fredric M. Jablin \& Linda L. Putnam (Eds). Thousand Oaks: SAGE.2001.

Fitch, Kate. 2009. "Making friends in the Wild West: Singaporean public relations practitioners' perceptions of working in social media" dalam PRism 6(2), hal 1-14.

Fitch, Kate. Making Friends in the Wild West: Singaporean Public Relations Practitioners' Perceptions of Working in Social Media.PRism Vol 6, No 2. 2009.

Flew, Terry.New Media. Oxford, Australia. 2004.

Gayatri, H Irine. LIPI.(Edisi 17 Desember 2012).Kekuatan Media Sosial dalam Pembentukan Opini Politik. Sumber: http://www.politik.lipi.go.id/in/kolom/politik-nasional/753-kekuatanmedia-sosial-dalam-pembentukan-opini-politik-.html.

Governement Social Research. (Mei 2016). Using social media for social research: An introduction. Social Media Research Group. Sumber: https://www.gov.uk/.../GSR_Social_Media_Research_Guidance_-

_Using_social_media_for_social_research.pdf.

Griffin, E.M. A First Look at Communication Theory 5th Edition. McGraw Hill, New York. 2003.

Guervitch, Michael, Coleman, Stephen, Blumler, Jay G. Political Communication -- Old and New Media Relationships. The ANNALS of the Amreican Academy of Political and Social Science. 2009.

Guervitch, Michael. , Coleman, Stephen., Blumler, Jay G. 2009. "Political Communication -Old and New Media Relationships" dalam The ANNALS of the Amreican Academy of Political and Social Science 625, hal.164-182.

Ibrahim, Idi Subandy. Lifestyle Ecstasy: Kebudayaan Pop dalam Masyarakat Komoditas Indonesia. Jalasutra, Yogyakarta. 1997.

J.Kaloh, Kepemimpinan Kepala Daerah (Pola Kegaiatan, Kekuasaan, dan Perilaku Kepala Daerah Dalam Pelaksanaan Otonomi Daearh), Sinar Grafika, Jakarta, 2009.

Joko. J. Prihatmoko, PILKADA Langsung, Pustaka Pelajar, Semarang, 2005.

KOMINFO.Kominfo : Pengguna Internet di Indonesia 63 Juta Orang. Sumber: https://kominfo.go.id/index.php/content/detail/3415/Kominfo+\%3A+Pengguna+Internet+di+In donesia+63+Juta+Orang/0/berita_satker. Diakses 17 Agustus 2017.

KPU.Data Pemilih Tetap Pilpres 2014 Wilayah Tulungagung. Sumber: https://data.kpu.go.id/ss8.php. 
Kurniawan, Dian. Liputan 6 (Episode 31 Maret 2017, 19:10 WIB). Tingkatkan Partisipasi PILKADA, KPU Jatim Resmikan Warok Ponorogo. Sumber: http://PILKADA.liputan6.com/read/2905977/tingkatkan-partisipasi-PILKADA-kpu-jatimresmikan-warok-ponorogo.

Lipiainen, Heini dan Karjaluotto, Heikki. 2012. "Suggestions For B2B Brand On Surviving In The Digital Age." Journal University of Helsinki. Vol 3, hal. 1-6.

Lipiainen, Heini dan Karjaluotto, Heikki. Suggestions For B2B Brand On Surviving In The Digital Age. Journal University of Helsinki.Vol 3. 2012.

Lubis, Heldania Utri. Detik News (Edisi Jumat 17 Februari 2017, 11:26 WIB).Partisipasi Pemilih Pilgub DKI 2017 78\%, Naik Jauh dari 2012. Sumber: https://news.detik.com/berita/d3425016/partisipasi-pemilih-pilgub-dki-2017-78-naik-jauh-dari-2012.

Momoc, Antonio. New Media and Social Media in the Political Communication. The 6th Edition of The International Conference European Integration-Realities and Perspectives. 2011.

Morgan, E, Snelson, C. Ellison-Bower, P. Image and video disclosure of substance use on social media websites. Computers in Human Behavior. 2010.

Morissan, dkk.Teori Komunikasi Massa. Ghalia Indonesia,Bogor. 2010.

Nurudin.Pengantar Komunikasi Massa.Depok : Raja Grafindo Persada. 2013.

Putra, Afdal Makkuraga. 2011. "Media Baru dan Fenomena Komunikasi Politik pada Pemilukada di Propinsi Banten 2011" dalam Jurnal UMN Volume III Nomor 2 Desember. Hal.23-34.

Putra, Afdal Makkuraga. Media Baru dan Fenomena Komunikasi Politik pada Pemilukada di Propinsi Banten 2011. Jurnal UMN, Vol III No 2. Desember. 2011.

Rakhmawaty.Republika. (Edisi Kamis, 17 Agustus 2017). Pemilih Muda Bakal Jadi Penentu. Sumber: http://www.republika.co.id/berita/koran/halaman-1/16/09/28/oe7cs34-pemilih-mudabakal-jadi-penentu.

Riaz, Saqib. 2010. "Effects on New Media Technologies on Political Communication" dalam Journal of Political Studies, Vol. 1, Issue 2 University of the Punjab Lahore, hal. 161-173.

Riaz, Saqib. Effects on New Media Technologies on Political Communication.Journal of Political Studies, Vol. 1, No 2.University of the Punjab Lahore. 2010.

Sasmita, Ira. Republika. (Edisi Rabu , 02 April 2014, 18:10 WIB). Media Sosial Bisa Genjot Partisipasi Pemilih. Sumber: http://www.republika.co.id/berita/pemilu/beritapemilu/14/04/02/n3ehor-media-sosial-bisa-genjot-partisipasi-pemilih.

Sastroatmodjo, Sudijono. Perilaku Politik. Ikip Semarang Press,Semarang. 1995.

Subekti, Tia. Partisipasi Politik Masyarakat dalam Pemilihan Umum: Studi Turn of Voter dalam Pemilihan Umum Kepala Daerah Kabupaten Magetan Tahun 2013. Skripsi Program Studi Ilmu Pemerintahan, Fakultas Ilmu Sosial dan Ilmu Politik Universitas Brawijaya. 2013.

Suharizal, Pemilukada: Regulasi, Dinamik, dan Konsep Mendatang. Jakarta: Raja Grafindo persada, 2011.

Surbakti, Ramlan. Memahami Ilmu Politik. Grasindo,Jakarta. 1999.

Surbakti, Ramlan. Partai Pemilu dan Demokrasi. Pustaka Pelajar,Yogyakarta. 1997.

Thelwall, M. Fk Yea I Swear: Cursing and Gender in MySpace. Corpora, 83-107. 2008.

Toppi, Aino Maijja. Corporate Brand Communication Through Social Media In industrial Setting. Journal University of Honolulu.Vol 2. 2012. 
Tufecki, Z. Big Questions for Social Media Big Data: Representativeness, Validity and Other Methodological Pitfalls. ICWSM '14: Proceedings of the 8th International AAAI Conference on Weblogs and Social Media, 2014. 2014.

Undang-Undang Nomor 1 Tahun 1945 tentang Peraturan Mengenai Kedudukan Komite Nasional Daerah.

Undang-Undang Nomor 1 tahun 1957 tentang Pokok-Pokok Pemerintahan Daerah (Lembaran Negara Republik Indonesia Tahun 1957 Nomor 6, Tambahan Lembaran Negara Republik Indonesia Nomor 1143).

Undang-Undang Nomor 1 Tahun 1957 tentang Pokok-Pokok Pemerintahan Daerah.Pasal 6 ayat 1 .

Undang-Undang Nomor 22 Tahun 1948 tentang Pokok-Pokok Pemerintahan Daerah.

Undang-Undang Nomor 22 Tahun 1999 tentang Pemerintahan Daerah.Pasal 34 ayat 1.

Undang-Undang Nomor 23 Tahun 2014 tentang Pemerintahan Daerah.

Undang-Undang Nomor 5 Tahun 1974 tentang Pokok-Pokok Pemerintahan Di Daerah ( Lembaran Negara Republik Indonesia tahun 1974 Nomor 38, Tambahan Lembaran Negara Republik Indonesia Nomor 3037).

Undang-Undang Nomor 5 Tahun 1974 tentang Pokok-Pokok Pemerintahan di Daerah.Pasal 16 ayat 1 .

Undang-Undang Nomor8 tahun 1965 tentang Pokok Pemerintahan Daerah (Lembaran Negara Republik Indonesia Tahun 1965 Nomor 83, Tambahan Lembaran Negara Republik Indonesia Nomor 2778).

Volkova, S., Bachrach, Y., Armstrong, M., \& Sharma, V. Inferring Latent User Properties from Texts Published in Social Media. Proceedings of the Twenty-Ninth AAAI Conference on Artificial Intelligence. Austin: AAAI.2015.

Wasesa, Silih Agung. 2011. Political Branding \& Public Relations. Jakarta: Gramedia Pustaka Utama.

Williams, M. Virtually Criminal Crime Deviance and Regulation Online. London: Routledge. 2006.

World Bank.Data.Population Total.Edisi $2017 . \quad$ Sumber: http://data.worldbank.org/indicator/SP.POP.TOTL. 